\title{
Şanlıurfa Sulu Koşullarında Bazı Çok Yıllık Sıcak Mevsim Buğdaygil Yem Bitkisi Türleriyle Yoncanın Saf ve Karışık Ekimlerinde Yem Kalite Değerlerinin
}

\section{Belirlenmesi}

\author{
Habip ARTAN ${ }^{1 *}$, Tahir POLAT ${ }^{2}$ \\ ${ }^{1}$ Habip ARTAN, Harran Üniversitesi Ziraat Fakültesi, Tarla Bitkileri Anabilim Dalı, Şanlıurfa, Türkiye. \\ ${ }^{2}$ Tahir POLAT, Harran Üniversitesi Ziraat Fakültesi, Tarla Bitkileri Anabilim Dalı, Şanlıurfa, Türkiye.
}

Geliş Tarihi: 27.02.2019

Kabul Tarihi: 30.05.2019

\begin{abstract}
Özet: Bu araştırma; Şanlıurfa sulu koşullarında bazı çok yıllık buğdaygil sıcak mevsim bitkisi türleri ile yoncanın saf ve karışım halinde ekimlerinde elde edilecek kuru madde verimi ile ot kalite özelliklerinin belirlenmesi amacıyla 2016 ve 2017 yıllarında yürütülmüştür. Araştırmada toplam 10 uygulama denenmiş olup, bunlar yonca (Medicago sativa), Rodos otu (Chloris gayana L.), köpekdişi ayrı̆ı̆ (Cynodon dactylon L.) ve adi yalancı darı (Paspalum dilatatum Poir.) türlerinin saf uygulamaları ile bu türlerin değişik kombinasyonlarından oluşan 6 karışım uygulamasından oluşmaktadır. İki yıllık ortalamalara göre, araştırmada incelenen özellikler aşağıdaki aralıklarda değişim göstermiştir; kuru madde verimi 335.57-729.79 kg/da, ham protein oranı \%8.73-\%21.50, ham protein verimi 33.91-176.21 kg/da, ADF oranı \%27.86-46.16, NDF oranı \%40.19-\%79.44 ve sindirilebilir kuru madde oranı (SKMO) \%52.94-\%67.20. Araştırma sonucuna göre; en yüksek kuru madde verimi, ham protein oranı, ham protein verimi, sindirilebilir kuru madde oranı ile beraber, en düşük ADF ve NDF oranına sahip saf yonca (1) uygulaması hem ot verimi hem de ot kalitesi bakımından en iyi uygulama olarak belirlenmiştir. Ancak yonca otunun yaş ot olarak hayvanlarda şişmeye neden olması nedeniyle, otlatma amaçlı mera tesislerinde, diğer karışımlardan daha yüksek kuru madde verimi ve ot kalitesine sahip olması nedeniyle, yonca (\%30) + Rodos otu (\%70) (5) ikili karışımı önerilmektedir. Anahtar Kelimeler: Karışım, Sıcak mevsim yem bitkileri, Yonca, Adi yalancıdarı, Rodos otu, Köpekdişsi ayrığı.
\end{abstract}

\section{Determining Forage Quality Values in Sole and Mixtures Sowings of Some Warm Season Perennial Grasses Species with Alfalfa in the Irrigated Conditions of Şanlıurfa}

\begin{abstract}
The study was conducted to determine dry matter yield and forage quality traits of some warm season perennial grasses species mixtures with alfalfa and their sole treatment in the irrigated conditions of Şanlıurfa during 2016 and 2017. The subjects of the study consisted of 10 treatments. There were 6 mixtures treatments between alfalfa and the warm season perennial grasses species. Also, there were sole treatment of alfalfa (Medicago sativa), rhodes grass (Chloris gayana L.) bermuda grass (Cynodon dactylon L.) and dallis grass (Paspalum diladatum Poir.). According to the two-years averages, the investigated traits had ranges as following; dry matter yield $335.57-729.79 \mathrm{~kg} / \mathrm{da}$, crude protein content $8.73 \%-21.50 \%$, crude protein yield 33.91-176.21 kg/da, ADF content $27.86-46.16 \%$, NDF content $40.19 \%-79.44 \%$, dry digestible matter ratio $52.94 \%-67.20 \%$. Results of the study revealed that the highest dry matter yield, crude protein content, crude protein yield and dry digestible matter ratio and the lowest ADF and NDF contents were in the sole alfalfa treatment. The results showed that sole alfalfa (1) treatment had the best forage yield and forage quality. Hence, alfalfa is recommended for dry forage production in Şanlıurfa conditions. On the other hand, due to bloating problem of fresh forage of alfalfa, when grazing aimed, alfalfa (30\%) + Rhodes (70\%) (5) binary mixture is recommended, because its dry matter yield and forage quality criteria were found superior to other mixtures treatments.

Keywords: Mixture, Warm season perennial grasses, Alfalfa, Dallis grass, Rhodes grass, Bermuda grass.
\end{abstract}

\section{Giriş}

Yem bitkileri, çiftlik hayvanlarının yaşayabilmeleri ve kendilerinden beklenen ürünleri verebilmeleri için vücutlarına almak zorunda oldukları besin maddelerini içeren ve belirli sınırlar içinde hayvanlara yedirildiğinde hayvan sağlığını ve hayvansal ürünleri olumsuz yönde etkilemeyen gerek kültürü yapılan ve gerekse doğada kendiliğinden yetişen bitkileri ifade etmektedir (Sayar, 2017). Esas olarak hayvan beslenmesinde çiftlik hayvanlarına ucuz ve kaliteli kaba yem sağlamasıyla önem arz eden yem bitkilerinin, aynı zamanda toprağa organik madde kazandırma, erozyonu önleme gibi faydaları da bulunmaktadır (Açıkgöz 2001; Geçit ve ark., 2009; Sayar 2017). Yem bitkilerinin karışık veya saf olarak yetiştirilmesinin en önemli faydalarından biri de doğal ot üretim kaynaklarımız olan meralar üzerindeki otlatma baskısının azaltılması gösterilebilir(Sayar ve ark., 2015).

Gelişmiş ülkelerde yem bitkileri tarımına çok büyük önem verilmekte olup, bu ülkeler tarım arazilerinin önemli kısımlarını yem bitkileri tarımına ayırmaktadırlar. Örneğin toplam tarla arazisi içerisinde yem bitkilerine ayrılan oran Avustralya'da \%49.8, Almanya'da \%36.5, Hollanda'da \%31.4; 
Fransa'da \%25.8, Ingiltere'de \%25.4 ve ABD'de \%23.0'tür. (Açıkgöz 2005; Sayar 2017).

Ülkemizde ise son yıllardaki yem bitkileri desteklemelerine paralel olarak tarla tarımı içerisindeki yem bitkileri oranı \%2-3'lerden \%7.4 seviyesine çıkmış, ancak Güneydoğu Anadolu Bölgesinde bu oran \%1.57 oranında kalmıştır. Ülkemizin mevcut kaba yem üretimi toplam kaba yem ihtiyacımızın yaklaşık yarısını karşılayabilmekte iken, bölgemizde mevcut kaba yem üretimi toplam kaba yem ihtiyacımızın yaklaşık 1/3'ünü karşılayabilmektedir. Yem bitkileri ile karşılanamayan kaliteli kaba yem açığı, saman ve anız artıkları gibi kalitesiz kaba yemlerle karşılanmaktadır (Sayar ve ark., 2010). Meralarımız ise yanlış ve aşırı otlatmalar nedeniyle verim kapasiteleri çok düşük düzeyde kalmıştır (Sayar ve ark., 2015).

Yonca, kurak ve yarı kurak bölgelerimizde kurulacak suni meraların en önemli baklagil bitkilerinden birisidir (Bakır, 1985). Baklagil ve buğdaygil yem bitkilerinin karışık olarak yetiştirilmesi, saf olarak ekimlerine göre büyük avantajlar sağlamaktadır (Karadağ ve Büyükburç 2004; Sayar ve Kendal, 2014). Birçok araştırıcı karışık ekimlerde ekolojik potansiyelin daha iyi değerlendirildiğini, birbiri ile uyumlu türlerin birlikte ekimi ile türlerin birbirlerinin gelişmesini hızlandırdığını, olumsuz çevre koşullarına dayanıklıı̆̆ın arttığını, karışımlardan elde edilen verimin ve ot kalitesinin yalnız ekime göre daha yüksek olduğunu bildirmektedirler (Vallentine, 1980; Avcıoğlu ve ark., 1991). Ancak, çok yıllık yem bitkilerinin karışım halinde yetiştirilmesinden beklenen yararların sağlanabilmesi için; karışım halinde yetiştirilecek yem bitkisi tür ve çeşitlerinin çok iyi belirlenmesi gerekmektedir. Her şeyden önce, karışımda bulunan türlerin kullanım amacına (biçme veya otlatma) uygun olması, büyüme mevsimlerinin benzer olması ve birbirleri ile çok fazla rekabet etmeden uzun süre birlikte kalabilecek türler olması gerekmektedir Bu koşulları yerine getirecek karışımlar ise ancak yapılacak araştırmalarla saptanabilmektedir (Altın ve ark., 2005).

Yonca yaş otunun içinde \%15.8 oranında bulunan saponin, hayvanların kan dolaşımını olumsuz yönde etkilemekte ve hayvan kayıplarına yol açabilmektedir (Avcıoğlu ve Soya, 2009). Bu yüzden yaş ot olarak otlatılacak mera karışımında yonca oranı \%30-40 seviyesini geçmemelidir. Suni mera tesisi için öngörülen sıcak iklim yem bitkileri (Rodos otu (Chloris gayana), Köpekdişi ayrığı (Cynodon dactylon) ve Adi yalancıdarı (Paspalum diladatum) + yonca karışımlarında yoncanın botanik kompozisyondaki oranı \%30-40'ı aşmamalıdır (Vallentine, 1980).
Yonca üzerinde Utah'da yapılan bir araştırmada saf yonca ile otlatılan besi sığırlarının dekara canlı ağırlık artışlarının 127.7 kg olduğunu buna karşın yonca+buğdaygil ikili karışımında otlatılan sığırların canlı ağırlık artışlarının $222.9 \mathrm{~kg}$ olduğu tespit edilmiştir. Ayrıca, yoncanın kuru maddede protein bakımından oldukça zengin olduğu (ort. \%17.33) bildirilmiştir (Chessmore, 1975).

Bazı amenejman tekniklerinin uygulanması sonucunda meradan kaynaklanan hayvanlarda şişme olayının azaltılabileceğini, hayvanlar tarafından seçiciliğin önlenmesi amacıyla, sınırlı bir alanda kısa süreli rotasyonlar şeklinde otlatılması gerektiği, hayvanların aç karnına sabah erken saatlerde, baklagil+buğdaygil karışımından meydana gelen meralarda otlatılmasının uygun olmadığı ifade edilmiştir (Vallentine, 1980).

Ball ve ark. (2001), kalite bakımından, genellikle baklagillerin buğdaygillerden daha iyi ot verdiğini, bunun sebebinin ise baklagillerin dokularında daha az lif bulunmasından kaynaklandığını, bu nedenle hayvanların baklagilleri daha fazla tükettiklerini, serin mevsim buğdaygil yem bitkilerinden daha kaliteli olduklarını, sindirilebilirliklerinin buğdaygillere göre yaklaşık olarak \%9 daha yüksek olduğunu ayrıca ham protein oranları bakımından daha yüksek proteine sahip olduğunu bildirmektedirler.

Serin ve Tan (2009), mera bitkisi olarak buğdaygillerin otlatmaya dayanıklılığının baklagillerden daha üstün olduğunu, meralarda buğdaygil yem bitkilerinin adaptasyon yeteneklerinin daha yüksek olduğunu, elverişli olmayan iklim ve toprak şartlarında ise doğal vejetasyonların dominant bitkilerini buğdaygil yem bitkilerinin oluşturduğunu bildirmişlerdir

Çınar (2012), Çukurova koşullarında 2009-2011 yılları arasında üç yıl süreli, bazı çok yıllık sıcak mevsim buğdaygil yem bitkilerinin yonca ile uygun karışımlarının performanslarının belirlenmesi üzerine yaptığı araştırmada, tesis yaşlandıkça, sıcak mevsim buğdaygil yem bitkilerinin botanik kompozisyondaki oranının düştüğü, buna karşın yonca oranının artmasının yanı sıra kalitesinin de arttığını, karışımdaki verimlerinin saf ekimlerden daha yüksek olduğunu bildirmiştir.

Bölgedeki yüksek yaz sıcaklıklarına dayanıklı bir baklagil olan yoncanın karışımlarda uygun oranda yer almasıyla, genelde düşük ham protein oranına sahip tropikal buğdaygillerden elde edilecek otun yem kalitesinin artırılması ile hayvanların ihtiyaç duyduğu protein miktarının karşılanması ve hayvancılı̆ın daha ekonomik hale getirilebilmesi amaçlanmaktadır. Yonca ve sıcak iklim yem bitkisi karışımlarının belirlenmesi ile ot üretiminin artırıması, hayvanların ihtiyaç duyduğu protein miktarının yükseltilmesi, bölgenin ekolojik 
potansiyelinden daha iyi yararlanılması ve kaba yem açığının kapatılmasına yardımcı olacaktır.

Bu araştırma; Şanlıurfa sulu koşullarında, sıcak iklim buğdaygil yem bitkisi türlerinden, Rodos Otu (Chloris gayana L.), Köpekdişi Ayrı̆̆ı/Bermuda Çimi (Cynodon dactylon L.) ve Adi Yalancıdarı (Paspalum dilatatum Poir.) türleriyle yoncanın (Medicago sativa L.) saf, ikili ve üçlü karışımlarının kuru madde verimi ve ot kalitesine etki eden önemli özelliklerin belirlenmesi amacıyla iki yıl süreyle yürütülmüştür.

\section{Materyal ve Metot}

Araştırma Harran Üniversitesi Osmanbey Kampüsünde yer alan Ziraat Fakültesi deneme alanında 2016 ve 2017 yıllarında yürütülmüştür. Araştırmada, çok yıllık sıcak mevsim buğdaygil yem bitkilerinden; Rodos otu (Chloris gayana), Köpekdişi ayrığı (Cynodon dactylon) ve Adi yalancıdarı (Paspalum diladatum) ile çok yıllık serin mevsim baklagil yem bitkilerinden yoncanın (Medicago sativa L.) saf ekimleri ile, bu türlerin değişik kombinasyonlarından oluşan 6 karışım uygulaması olmak üzere Tablo 1'de belirtilen toplam 10 uygulama denenmiştir.

Tablo 1. Araştırma uygulamaları ve uygulama kodları.

\begin{tabular}{ll}
$\begin{array}{l}\text { Uygulama } \\
\text { Kodu }\end{array}$ & Uygulamalar \\
\hline 1 & Saf Yonca (Medicago sativa L.) \\
2 & Saf Rodos Otu (Chloris gayana) \\
3 & Saf Adi Yalancı darı (Paspalum diladatum) \\
4 & Saf Köpek dişi Ayrı̆̆ı (Cynodon dactylon) \\
5 & Yonca (\%30) + Rodos otu. (\%70) \\
6 & Yonca (\%30) + Adi yalancı darı (\%70) \\
7 & Yonca (\%30) + Köpek dişi ayrığı (\%70) \\
8 & Yonca (\%30) +Rodos otu. (\%35)+ Adi yalancı darı (\%35) \\
9 & Yonca $(\% 30)+$ Rodos otu (\%35)+ Köpek dişi ayrı̆̆ (\%35) \\
10 & Yonca (\%30) + Köpek dişi ayrı̆̆ı (\%35)+Adi yalancı darı (\%35) \\
\hline
\end{tabular}

Araştırmada kullanılan bitki materyaline ait bilgiler Tablo 2'de verilmiştir.

Tablo 2. Araştırmada kullanılan çok yıllık buğdaygil ve baklagil yem bitki türlerinin isimleri ve orijinleri.

\begin{tabular}{|c|c|c|c|}
\hline Tür & Kısaltma & Çeşit & Orijini \\
\hline $\begin{array}{l}\text { Yonca } \\
\text { (Medico sativa L.) }\end{array}$ & (YONCA) & Elçi & Türkiye \\
\hline $\begin{array}{l}\text { Rodos Otu } \\
\text { (Chloris gayana) }\end{array}$ & (RODOS) & $\begin{array}{l}\text { Popul } \\
\text { asyon }\end{array}$ & $\begin{array}{l}\text { Doğu Akdeniz } \\
\text { Araştırma } \\
\text { Enstitüsü }\end{array}$ \\
\hline $\begin{array}{l}\text { Adi Yalancidarı } \\
\text { (Paspalum } \\
\text { diladatum) }\end{array}$ & (AYD) & $\begin{array}{l}\text { Popul } \\
\text { asyon }\end{array}$ & $\begin{array}{l}\text { Doğu Akdeniz } \\
\text { Araştırma } \\
\text { Enstitüsü }\end{array}$ \\
\hline $\begin{array}{l}\text { Köpekdişi Ayrı̆̆ı } \\
\text { (Cynodon } \\
\text { dactylon) }\end{array}$ & (KDA) & $\begin{array}{l}\text { Berm } \\
\text { uda } \\
\text { grass }\end{array}$ & Uganda \\
\hline
\end{tabular}

Araştırmada saf ekimlerde, yoncada $1 \mathrm{~kg} / \mathrm{da}$, Rodos otunda $0.5 \mathrm{~kg} / \mathrm{da}$, Adi yalancı darıda $1.2 \mathrm{~kg} / \mathrm{da}$, köpek dişi ayrığında ise $1.2 \mathrm{~kg} / \mathrm{da}$ tohum kullanılmıştır. Karışımlarda kullanılan tohumluk miktarları ise Tablo 1'de belirtilen karışım oranları nispetinde, her türün saf ekimde kullanılan tohumluk miktarı ile kıyaslanarak karışımlarda kullanılacak toplam tohumluk miktarı hesaplanmıştır. Saf türler ve karışımlara uygulanacak tohumluklar homojen bir şekilde karıştırılarak 10 Mayıs 2016 tarihinde açılan çizilere elle ekim yapılmıştır. Tesadüf blokları deneme desenine göre 3 tekerürlü olarak kurulan denemede, parsel sıra sayısı 8, iki sıra arası mesafe $25 \mathrm{~cm}$, sıra uzunluğu $3 \mathrm{~m}$ olmak üzere, her bir parsel büyüklüğü $6 \mathrm{~m}^{2}$ olmuştur.

Tablo 3. Deneme alanı topraklarına ait bazı fiziksel ve kimyasal özellikler.

\begin{tabular}{|c|c|c|c|c|c|c|}
\hline Toprak & ile & $\begin{array}{l}\text { Su ile } \\
\end{array}$ & Kireç & Fosfor & Potasyum & Organik \\
\hline Derinliǧi & Doygunluk & Doymuş & (CaCo3) & $\left(\mathrm{P}_{2} \mathrm{O}_{5}\right)$ & $\left(\mathrm{K}_{2} \mathrm{O}\right)$ & Madde \\
\hline \multirow[t]{2}{*}{ (cm) } & (\%) & Toprakta & (\%) & $(\mathrm{Kg} / \mathrm{da})$ & $(\mathrm{kg} / \mathrm{da})$ & (\%) \\
\hline & & $\mathrm{pH}$ & & & & \\
\hline $0-20$ & 64 & 7.78 & 29.20 & 1.3 & 30.05 & 0.28 \\
\hline
\end{tabular}

Tablo 3'de araştırmanın yürütüldüğü yere ait, 0-20 cm'lik üst katmandan alınan toprak örneklerinden saptanmış olunan toprak analiz sonuçları verilmiştir. Tablo 3 incelendiğinde, araştırma yeri topraklarının killi tınlı bünyede, hafif bazik karekterde, fosfor ve organik madde içeriği bakımından fakir, kireç ve potasyum içeriği bakımından zengin olduğu belirlenmiştir. Ayrıca araştırma yeri topraklarının genel yapısı olarak verimli toprak profili ince ve verim düzeyi düşük kıraç arazi olduğu söylenebilir. Nitekim arazinin bu şekilde olması kuru madde verimlerinin düşük olmasına neden olmuştur. Araştırmada deneme alanı ekim sırasında dekara 10 saf azot düşecek şekilde gübrelenirken, daha sonra her biçimden sonra 5'er $\mathrm{kg}$ azot gübresi ile gübrelenmiştir (Hatipoğlu ve Tükel, 2009; Avcl, 2000).

Şanlıurfa iline ait 2016 ve 2017 yılları ile uzun yıllar ortalaması aylık ortalama sıcaklık, aylık ortalama nisbi nem ve toplam yağış miktarları Tablo 4'de verilmiştir. Tablo 4 incelendiğinde, Şanlıurfa ilinde denemenin yürütüldüğü 2016 ve 2017 yıllarında kaydedilen ortalama sıcaklık değerlenin genel olarak uzun yıllar ortalamasından daha yüksek, nisbi nem değerlerinin ise daha düşük olduğu belirlenmiştir. Öte yandan, araştırmanın yürütüldüğü her iki yılda da kaydedilen toplam yağış miktarları uzun yıllar ortalamasının çok altında olmuştur. Bununla beraber 2017 yılında kaydedilen toplam yağış, 2016 yılında kaydedilen toplam yağıştan fazla olmuştur.

Araştırmada kuru madde verimi ile beraber ot kalitesini belirleyen önemli özellikler incelenmiştir. Yeşil ot verimi tespiti için $6 \mathrm{~m}^{2 \prime}{ }^{\prime}$ lik her bir parsellerden tesadüfü olarak seçilen $50 \times 50 \mathrm{~cm}$ 'lik üçer adet $\left(0.25 \mathrm{~m}^{2}\right)$ alan el ile biçilerek saf olan bitkiler doğrudan tartılmış, karışımı oluşturan parseldeki bitkiler ise türlerine ayrıştırılarak ayrı ayrı tartılmış ve ayrı kağıt poşetlerde muhafaza edilerek açık havada kurutulmaya bırakılmıştır. Biçim 
makinesi ile her bir parsel ayrı ayrı biçilerek yeşil ot ağırlığı tartılmış, her bir parseldeki saf ve karışımları oluşturan türlerin dekara yaş ot ve kuru ot verimleri hesaplanmıştır.

Tabo 4. Şanlıurfa ilinin 2016-2017 yılı ve uzun yıllara ait iklim değerleri.

\begin{tabular}{|c|c|c|c|c|c|c|c|c|c|}
\hline \multirow{3}{*}{ Aylar } & \multicolumn{3}{|c|}{ Ortalama Sıcaklık $\left({ }^{\circ} \mathrm{C}\right)$} & \multicolumn{3}{|c|}{ Toplam Yağış(kg/m²) } & \multicolumn{3}{|c|}{ Nisbi Nem (\%) } \\
\hline & 2016 & 2017 & Uzun & 2016 & 2017 & Uzun Yıl Ort. & 2016 & 2017 & Uzun \\
\hline & Yılı & Yılı & Yıl Ort. & Yılı & Yılı & & Yılı & Yılı & Yıl Ort. \\
\hline Ocak & 4.7 & 5.4 & 5.7 & 95.6 & 9.0 & 85.7 & 70.3 & 61.9 & 70.3 \\
\hline Mart & 13.6 & 12.7 & 11.0 & 13.0 & 55.2 & 64.1 & 50.3 & 57.1 & 60.4 \\
\hline Nisan & 20.6 & 16.6 & 16.2 & 27.1 & 79.2 & 46.8 & 36.1 & 50.2 & 56.2 \\
\hline Temmuz & 33.0 & 34.2 & 31.9 & 0.2 & 0.0 & 0.6 & 25.4 & 22.9 & 30.0 \\
\hline Ağustos & 33.2 & 32.2 & 31.2 & 0.0 & 0.0 & 0.8 & 30.6 & 35.7 & 33.1 \\
\hline Eylül & 26.4 & 29.6 & 26.8 & 0.0 & 0.0 & 3.3 & 32.1 & 28.8 & 35.8 \\
\hline Ekim & 22.1 & 20.5 & 20.2 & 22.0 & 17.1 & 27.4 & 35.9 & 36.9 & 46.4 \\
\hline Kasım & 12.6 & 13.4 & 12.7 & 23.3 & 17.4 & 46.0 & 42.9 & 56.0 & 59.9 \\
\hline
\end{tabular}

Tablo 5. Bazı çok yıllık yem bitkilerinin saf ve karışık ekim uygulamalarında saptanmış olunan kuru madde verimi (kg/da) ve ham protein oranlarına (\%) ilişkin değerler ve oluşan gruplar.

\begin{tabular}{|c|c|c|c|c|c|c|c|}
\hline \multirow{3}{*}{ No } & \multirow{3}{*}{ Uygulamalar } & \multicolumn{3}{|c|}{ Kuru madde verimi (kg/da) } & \multicolumn{3}{|c|}{ Ham protein oranı (\%) } \\
\hline & & \multicolumn{2}{|c|}{ Yıllar } & \multirow{2}{*}{ Ort. } & \multicolumn{2}{|c|}{ Yıllar } & \multirow{2}{*}{ Ort. } \\
\hline & & 2016 & 2017 & & 2016 & 2017 & \\
\hline 1 & SAF- YONCA & $510.7^{\dagger}$ & $948.8^{\mathrm{a}}$ & $729.8^{a}$ & $21.30^{\mathrm{a}}$ & $21.69^{\mathrm{a}}$ & $21.50^{\mathrm{a}}$ \\
\hline 2 & SAF-RODOS (R) & $555.8^{\mathrm{ef}}$ & $345.6^{\text {hI }}$ & $450.7^{\dagger}$ & $10.60^{\mathrm{g}}$ & $10.10^{\mathrm{g}}$ & $10.35^{\mathrm{c}}$ \\
\hline 3 & SAF-ADI YALANCI DARI (AYD) & $343.0^{\mathrm{hl}}$ & $363.4^{\text {gh }}$ & $353.2^{\mathrm{g}}$ & $10.01^{\mathrm{g}}$ & $7.46^{\mathrm{h}}$ & $8.73^{d}$ \\
\hline 4 & SAF-KÖPEKDIŞI AYRIĞI (KDA) & $286.2^{1}$ & $569.4^{\mathrm{ef}}$ & $427.8^{f}$ & $13.62^{f}$ & $9.79^{\mathrm{g}}$ & $11.71^{\mathrm{c}}$ \\
\hline 5 & $\% 30-Y O N C A+\% 70$ RODOS & $601.8^{\text {de }}$ & $786.6^{b}$ & $694.2^{\mathrm{ab}}$ & $16.59^{\text {be }}$ & $7.47^{\text {bd }}$ & $17.03^{b}$ \\
\hline 6 & $\% 30-Y O N C A+\% 70$ AYD & $329.0^{\mathrm{hl}}$ & $724.9^{b c}$ & $526.9^{e}$ & $18.28^{\mathrm{bc}}$ & $14.65^{\mathrm{ef}}$ & $16.47^{b}$ \\
\hline 7 & $\% 30-Y O N C A+\% 70$ KDA & $162.6^{J}$ & $508.5^{\dagger}$ & $335.6^{\mathrm{g}}$ & $18.68^{\mathrm{b}}$ & $15.37^{\mathrm{df}}$ & $17.03^{b}$ \\
\hline 8 & $\% 30-Y O N C A+\% 35$ R+\%35 AYD & $543.5^{\mathrm{ef}}$ & $719.1^{\mathrm{c}}$ & $631.3^{\mathrm{cd}}$ & $16.18^{\mathrm{ce}}$ & $15.36^{\mathrm{df}}$ & $15.77^{b}$ \\
\hline 9 & \%30-YONCA+\%35 R+\%35 KDA & $579.6^{\text {de }}$ & $635.5^{d}$ & $607.5^{d}$ & $16.06^{\text {de }}$ & $15.39^{\mathrm{df}}$ & $15.72^{b}$ \\
\hline 10 & \%30-YONCA+\%35 KDA+\%35 AYD & $419.0^{\mathrm{g}}$ & $908.0^{\mathrm{a}}$ & $663.5^{b c}$ & $16.27^{\text {ce }}$ & $14.77^{\mathrm{ef}}$ & $15.52^{b}$ \\
\hline Yıllar & & $433.1^{b}$ & $651.0^{\mathrm{a}}$ & 542.1 & 15.76 & 13.21 & 14.98 \\
\hline D.K. 1 & & 7.32 & & & 8.75 & & \\
\hline \multicolumn{8}{|c|}{ LSD (\%5) } \\
\hline \multicolumn{2}{|c|}{ Yıllar } & $20.88 * *$ & & & $0.69 * *$ & & \\
\hline \multicolumn{2}{|c|}{ Uygulamalar } & $46.48 * *$ & & & $1.54 * *$ & & \\
\hline \multicolumn{2}{|c|}{ Yıl x Uygulama } & $65.73 * *$ & & & $2.17^{*}$ & & \\
\hline
\end{tabular}

Tablo 6. Bazı çok yıllık yem bitkilerinin saf ve karışık ekim uygulamalarında saptanmış olunan ham protein verimi (kg/da) ve ADF oranlarına (\%) ilişkin değerler ve oluşan gruplar.

\begin{tabular}{|c|c|c|c|c|c|c|c|}
\hline \multirow{3}{*}{ No } & \multirow{3}{*}{ Uygulamalar } & \multicolumn{3}{|c|}{ Ham protein verimi $(\mathrm{kg} / \mathrm{da})$} & \multicolumn{3}{|c|}{ ADF (\%) } \\
\hline & & \multicolumn{2}{|c|}{ Yıllar } & \multirow{2}{*}{ Ort. } & \multicolumn{2}{|c|}{ Yillar } & \multirow{2}{*}{ Ort } \\
\hline & & 2016 & 2017 & & 2016 & 2017 & \\
\hline 1 & SAF- YONCA & $120.9^{c}$ & $231.5^{\mathrm{a}}$ & $176.2^{\mathrm{a}}$ & $27.18^{\prime}$ & $28.53^{\text {hI }}$ & $27.86^{\dagger}$ \\
\hline 2 & SAF-RODOS (R) & $64.9^{\mathrm{h}}$ & $39.0^{\prime}$ & $52.0^{e}$ & $42.22^{b}$ & $39.83^{b c}$ & $41.03^{b}$ \\
\hline 3 & SAF-ADI YALANCI DARI (AYD) & $37.7^{\prime}$ & $30.1^{\prime}$ & $33.9^{f}$ & $45.54^{\mathrm{a}}$ & $46.78^{\mathrm{a}}$ & $46.16^{\mathrm{a}}$ \\
\hline 4 & SAF-KÖPEKDIŞi AYRIĞI (KDA) & $43.6^{\prime}$ & $62.1^{\mathrm{h}}$ & $52.9^{\mathrm{e}}$ & $32.93^{\mathrm{eg}}$ & $35.91^{\text {de }}$ & $34.42^{\mathrm{cd}}$ \\
\hline 5 & $\% 30-Y O N C A+\% 70$ RODOS & $111.6^{\mathrm{ce}}$ & $154.6^{\mathrm{b}}$ & $133.1^{b}$ & $32.90^{\mathrm{eg}}$ & $31.86^{\mathrm{fg}}$ & $32.38^{\text {de }}$ \\
\hline 6 & $\% 30-Y O N C A+\% 70$ AYD & $66.7^{\mathrm{h}}$ & $118.3^{\mathrm{cd}}$ & $92.5^{d}$ & $31.77^{\mathrm{fg}}$ & $37.75^{\mathrm{cd}}$ & $34.76^{c}$ \\
\hline 7 & $\% 30-Y O N C A+\% 70$ KDA & $34.0^{\prime}$ & $88.2^{\mathrm{fg}}$ & $61.1^{\mathrm{e}}$ & $27.64^{h_{1}}$ & $33.22^{\mathrm{eg}}$ & $30.43^{\mathrm{e}}$ \\
\hline 8 & \%30-YONCA+\%35 R+\%35 AYD & $96.9^{\text {ef }}$ & $122.6^{\mathrm{C}}$ & $109.8^{c}$ & $34.33^{\mathrm{ef}}$ & $35.07^{\text {de }}$ & $34.70^{c}$ \\
\hline 9 & $\% 30-Y O N C A+\% 35$ R+\%35 KDA & $103.7^{\text {de }}$ & $110.1^{\mathrm{ce}}$ & $106.9^{c}$ & $33.43^{\mathrm{eg}}$ & $34.33^{\mathrm{ef}}$ & $33.88^{\mathrm{cd}}$ \\
\hline 10 & \%30-YONCA+\%35 KDA+\%35 AYD & $75.2^{\mathrm{gh}}$ & $149.5^{b}$ & $112.3^{\mathrm{c}}$ & $30.64^{\mathrm{gh}}$ & $34.65^{d f}$ & $32.65^{\mathrm{ce}}$ \\
\hline Yilla & & $75.5 b$ & $110.6 a$ & 93.1 & $33.86^{b}$ & $35.79^{a}$ & 34.83 \\
\hline D.K. & & 9.99 & & & 5.48 & & \\
\hline \multicolumn{8}{|c|}{ LSD (\%5) } \\
\hline \multicolumn{2}{|c|}{ Yıllar } & $4.87 * *$ & & & $0.99 * *$ & & \\
\hline \multicolumn{2}{|c|}{ Uygulamalar } & $10.89 * *$ & & & $2.23 * *$ & & \\
\hline \multicolumn{2}{|c|}{ Yıl x Uygulama } & $15.39 * *$ & & & $3.14 * *$ & & \\
\hline
\end{tabular}

+, aynı sütun içerisinde benzer harf grubu ile gösterilen ortalamalar, LSD (\% 5)'e göre farklı değildir; *, \% 5 düzeyinde öne mli; **, \% 1 düzeyinde önemli, ÖD; önemli değil. 
Tablo 7. Bazı çok yıllık yem bitkilerinin saf ve karışık ekim uygulamalarında saptanmış olunan NDF oranları (\%) ve sindirilebilir kuru madde oranlarına (\%) ilişkin değerler ve oluşan gruplar.

\begin{tabular}{|c|c|c|c|c|c|c|c|}
\hline \multirow{3}{*}{ No } & \multirow{3}{*}{ Uygulamalar } & \multicolumn{3}{|c|}{ NDF (\%) } & \multicolumn{3}{|c|}{ SKMO (\%) } \\
\hline & & \multicolumn{2}{|c|}{ Yıllar } & \multirow{2}{*}{ Ort. } & \multicolumn{2}{|c|}{ Yıllar } & \multirow{2}{*}{ Ort. } \\
\hline & & 2016 & 2017 & & 2016 & 2017 & \\
\hline 1 & SAF- YONCA & 42.56 & 37.83 & 40.19 & $67.72^{\mathrm{a}}$ & $66.68^{\mathrm{ab}}$ & $67.20^{\mathrm{a}}$ \\
\hline 2 & SAF-RODOS (R) & 75.85 & 74.35 & 75.10 & $56.01^{\mathrm{h}}$ & $57.87^{\text {gh }}$ & $56.94^{e}$ \\
\hline 3 & SAF-ADI YALANCI DARI (AYD) & 79.21 & 79.66 & 79.44 & $53.42^{1}$ & $52.45^{1}$ & $52.94^{\dagger}$ \\
\hline 4 & SAF-KÖPEKDIŞi AYRIĞI (KDA) & 69.79 & 68.78 & 69.29 & $63.25^{\mathrm{ce}}$ & $60.93^{\mathrm{ef}}$ & $62.09^{\mathrm{cd}}$ \\
\hline 5 & $\% 30-Y O N C A+\% 70$ RODOS & 55.28 & 51.22 & 53.25 & $63.27^{\text {ce }}$ & $64.08^{c d}$ & $63.68^{b c}$ \\
\hline 6 & $\% 30-Y O N C A+\% 70$ AYD & 52.25 & 58.47 & 55.36 & $64.15^{\mathrm{cd}}$ & $59.49^{\mathrm{fg}}$ & $61.82^{d}$ \\
\hline 7 & $\% 30-Y O N C A+\% 70$ KDA & 50.32 & 56.11 & 53.22 & $67.37^{\mathrm{ab}}$ & $63.02^{\mathrm{ce}}$ & $65.20^{\mathrm{b}}$ \\
\hline 8 & $\% 30-Y O N C A+\% 35$ R+\%35 AYD & 60.49 & 58.46 & 59.48 & $62.16^{\mathrm{de}}$ & $61.58^{\mathrm{ef}}$ & $61.87^{d}$ \\
\hline 9 & \%30-YONCA+\%35 R+\%35 KDA & 58.82 & 58.01 & 58.41 & $62.86^{\mathrm{ce}}$ & $62.16^{\text {de }}$ & $62.51^{\mathrm{cd}}$ \\
\hline 10 & $\% 30-Y O N C A+\% 35$ KDA+\%35 AYD & 57.70 & 58.46 & 58.08 & $65.03^{b c}$ & $61.90^{\mathrm{df}}$ & $63.47^{\text {bd }}$ \\
\hline Yilla & & 60.23 & 60.13 & 60.18 & 62.52 & 61.02 & 61.77 \\
\hline D.K. & & 5.08 & & & 2.42 & & \\
\hline \multicolumn{8}{|c|}{ LSD (\%5) } \\
\hline \multicolumn{2}{|c|}{ Yillar } & ÖD & & & $0.77^{* *}$ & & \\
\hline \multicolumn{2}{|c|}{ Uygulamalar } & ÖD & & & $1.75^{* *}$ & & \\
\hline \multicolumn{2}{|c|}{ Yıl x Uygulama } & ÖD & & & $2.47 * *$ & & \\
\hline
\end{tabular}

+, aynı sütun içerisinde benzer harf grubu ile gösterilen ortalamalar, LSD (\% 5)'e göre farklı değildir; *, \% 5 düzeyinde önemli; **, \% 1 düzeyinde önemli, ÖD, önemli değil.

Kuru madde verimi (KMV) (kg/da): Doğal ortamda kurutulmuş, saf ve karışımlardan oluşan her bir türden 5'er gramlık öğütülmüş numune alınarak C0904FE-Hay and Fresh Forage kalibrasyonu kullanılarak Yakın Kızıl Ötesi Spektroskopisi (NIRS) analiz cihazıyla her bir türün kuru madde oranları bulunmuştur. Her bir türün kuru madde oranları bulunduktan sonra daha önceden bulunan dekara kuru ot miktarları ile çarpılarak kuru madde verimleri belirlenmiştir.

Ham protein oranı (HPO) (\%): Doğal ortamda kurutulmuş, saf ve karışımlardan oluşan her bir türden 5'er gramlık numunelerden, C-0904FE-Hay and Fresh Forage kalibrasyonu kullanılarak Yakın Kızıl Ötesi Spektroskopisi (NIRS) analiz cihazıyla her bir türün ham protein oranı (HPO) \% olarak belirlenmiştir.

Ham protein verimi (HPV) (kg/da): Saf ve karışımı oluşturan türlerin daha önceden bulunan ham protein oranları ile dekara kuru ot verimleri çarpılarak saf tür ve karışımların ham protein verimleri (HPV) $\mathrm{kg} /$ da olarak hesap edilmiştir.

Asit deterjan lif (ADF) oranı (\%) : Doğal ortamda kurutulmuş, saf ve karışımlardan oluşan her bir türden 5'er gramlık numunelerden, C0904FE-Hay and Fresh Forage kalibrasyonu kullanılarak Yakın Kızıl Ötesi Spektroskopisi (NIRS) analiz cihazıyla her bir türün ADF oranı belirlenmiştir.

Nötral deterjan lif (NDF) oranı (\%) : Doğal ortamda kurutulmuş, saf ve karışımlardan oluşan her bir türden 5'er gramlık numunelerden, C-0904FE-Hay and Fresh Forage kalibrasyonu kullanılarak Yakın
Kızıl Ötesi Spektroskopisi (NIRS) analiz cihazıyla her bir türün NDF oranı belirlenmiştir.

Sindirilebilir kuru madde oranı (SKMO) (\%) : Daha önce bulunan ADF sonuçlarından yararlanılarak Schroeder (1994) ve Sheaffer ve ark. (1995) tarafından önerilen aşağıdaki formül aracılığıyla hesaplanmıştır.

Sindirilebilir kuru madde oranı (SKMO) $(\%)=88.90$ (0.779 x ADF \%).

Araştırmada ot biçimleri, saf ekimlerde türlerin çiçeklenme başlangıcı zamanında, saf yonca ve karışım parsellerinde ise yoncanın 1/10 çiçeklenme dönemi dikkate alınarak yapılmıştır (Serin ve ark., 1997). Birinci yılda; saf ve karışımı oluşturan parsellerde sırasıyla 18 Temmuz, 25 Ağustos, 28 Eylül ve $08 \mathrm{Kasım}$ tarihlerinde toplam dört biçim yapılmıştır. İkinci yılda ise; 26 Nisan'da sadece yoncadan, 24 Mayıs'ta yonca ve köpek dişi ayrı̆̆ından, 20 Haziran'da sadece yoncadan, 20 Temmuz, 28 Ağustos ve 04 Ekimde ise tüm saf ve karışım parsellerinde toplamda altı biçim yapılmıştır. Araştırma alanı yağmurlama sulama şeklinde yaz boyunca haftada 1 kez sulanmıştır. Sulamanın deneme biçimlerden hemen sonra yapılmasına dikkat edilmiştir.

Araştırma sonucunda elde edilen iki yıllık veriler birleştirilerek varyans analizleri JMP 5.0.1 istatistik paket programında yapılmış, ortalamalar arası farklılık, LSD (\% 5) çoklu karşılaştırma testine göre belirlenmiştir.

\section{Bulgular}

Araştırmada incelenen kuru madde verimi ve ham protein oranı özellikleri ile ilgili veriler Tablo 5 'de verilmiştir. Tablo 5 incelendiğinde; araştırma yılları, uygulamalar ve yıl $x$ uygulama 
interaksiyonlarının kuru madde verimi için 0.01 düzeyinde, ham protein oranı özelliği için ise yıllar ve uygulamalar için 0.01 düzeyinde, yıl x uygulama interaksiyonu için ise 0.05 düzeyinde önemli olduğu görülmektedir. Araştırmada 2016 yılında elde edilen kuru madde verimi (433.1 kg/da), 2017 yılında elde edilen kuru madde veriminden $(651.0 \mathrm{~kg} / \mathrm{da})$ daha düşük bulunurken, ham protein oranları ise tam tersi bir durum göstererek 2017 yılında (\%15.76) daha yüksek bulunmuştur. Tablo 5 'te yıl x uygulama interaksiyonları incelendiğinde, kuru madde verimleri uygulamalar ve yıllar arasında $162.6 \mathrm{~kg} / \mathrm{da}$ ile $948.8 \mathrm{~kg} / \mathrm{da}$ arasında değişim gösterirken, ham protein oranları ise \%7.46 ile \%21.69 arasında değişim göstermiştir. İki yıllık ortalama veriler dikkate alındığında ise, en yüksek kuru madde verimi saf yonca (1) uygulaması ile 5 nolu karışım (\%30-yonca+ \%70 Rodos otu) uygulamasından elde edilirken, en yüksek ham protein oranı sadece saf yonca uygulamasından elde edilmiştir.

Araştırmada ham protein verimi (HPV) ve asit deterjanda çözünmeyen lif oranı (ADF) özellikleri bakımından tüm interaksiyonlar 0.01 düzeyinde önemli bulunmuştur. Yıllar ortalamasına göre, araştırmanın 2017 yılında elde edilen ham protein verimi (110.6 kg/da) ile ADF oranı (\%35.79), 2016 yılında elde edilenden daha yüksek bulunmuştur (Tablo 6). Yıl x uygulama interaksiyonu Tablo 6'da incelendiğinde yıllar ve uygulamalar arasında ham protein verimi $30.14 \mathrm{~kg} / \mathrm{da}$ ile $231.52 \mathrm{~kg} / \mathrm{da}$ arasında, ADF oranları ise \%27.18 ile \%46.78 arasında değişim göstermiştir. İki yıllık ortalamalara göre; en yüksek ham protein verimi saf yonca (1) uygulamasından elde edilirken, en düşük ham protein verimi ise saf adi yalancı darı (3) uygulamasından elde edilmiştir. ADF oranları ise ham protein verimi özelliğinin tersi olarak en yüksek oran saf adi yalancı darı (3) uygulamasından $(\% 46,16)$, en düşük saf yonca (1) uygulamasından (\%27.86) elde edilmiştir.

Araştırmada nötral deterjanda çözünmeyen lif oranı (NDF) özelliği bakımından yıl, uygulama ve yıl $x$ uygulama interaksiyonu istatiksel olarak önemsiz bulunmuştur. Sindirilebilir kuru madde oranı (SKMO) bakımndan ise tüm interaksiyonlar 0.01 düzeyinde önemli bulunmuştur. Araştırmada yıl $x$ uygulama interaksiyonu incelendiğinde, yıllar ve uygulamalar arasında NDF oranları \%37.83 ile \%79.66 arasında değişim gösterirken, SKMO değerleri ise \%52.45 ile \%67.72 arasında değişim göstermiştir. İki yıllık ortalamalara göre; en yüksek sindirilebilir kuru madde oranı (\%67.20) saf yonca uygulamasında, en düşük sindirilebilir kuru madde oranı saf adi yalancı darı (3) uygulamasında saptanmıştır (Tablo 7).

\section{Tartışma ve Sonuç}

Araştırmada çok yıllık sıcak mevsim buğdaygil yem bitkisi türleri ile yoncanın saf ve değişik kombinasyonlarından oluşan karışımlardan meydana gelen uygulamalarda, NDF özelliği dışındaki tüm özellikler için yıllar, uygulamalar ve yıl $x$ uygulama interaksiyonu istatiksel olarak önemli bulunmuştur $(\mathrm{P}<0.05)$ (Tablo $5,6,7)$. Yıl x uygulama interaksiyonun NDF dışındaki özellikler için önemli olması, yıllar arasında değişen çevre şartlarının, incelenen bu özellikler bakımından uygulamalar arasındaki sıralamaya önemli derecede etki ettiğini göstermektedir (Sayar ve ark., 2013; Sayar ve ark., 2014; Kendal ve ark., 2016).

Araştırmada 2017 yılında elde edilen kuru madde verimleri, 2016 yılında elde edilenlerden daha yüksek bulunmuştur (Tablo 5). Kuru madde verimlerinde 2016 yılının daha geride kalmasının nedeni olarak; bu yılın tesis yılı olması nedeniyle biçim sayısının az olması ve bu yılda kaydedilen yağış miktarının düşük olması gösterilebilir. Bulgularımızla paralel olarak, bir çok araştırıcı tesis yılında karışım ve saf uygulamalarda daha düşük kuru madde verimi elde ettiklerini bildirmişlerdir (Avcı, 2000; Albayrak, 2003; Sayar ve ark., 2014). Ayrıca yonca ile adi yalancı darının yer aldığı ikili karışım parsellerinde ikinci yıldaki kuru madde verimindeki artış yaklaşık iki katına çıktığı gözlenmiştir (Tablo 5), bunun sebebinin ise yoncada ışık rekabetinin daha yüksek olduğu ve sıcaklıklara karşı diğer serin mevsim yem bitkilerine göre daha dayanıklı olduğu, ikinci yılda daha iyi gelişen kök sistemi ile açıklamak mümkündür (Çınar, 2012).

Kuru madde veriminin tersi olarak 2016 yılında uygulamalardan elde ham protein oran 2017 den daha yüksek bulunmuştur (Tablo 5). Bulgularımızla uyumlu olarak Kendal ve ark. (2016) ham protein oranı ile verim arasında ters ilişki olduğunu bildirmişlerdir. Ayrıca, araştırmada kuru madde verimi ve ham protein oranı özelliklerine ilişkin saptamış olduğumuz bulgular, Sayar ve ark. (2014)'nın bazı çok yıllık buğdaygil yem bitkilerinin saf ekimlerinde elde ettikleri kuru madde verimleriyle uyum gösterirken, aynı çalışmada yonca ve yonca içeren buğdaygil karışımlarından elde ettikleri kuru madde verim değerlerinden düşük bulunmuştur. Her iki çalışmada elde edilen ham protein oranları ise uyum göstermektedir. Ayrıca araştırmanın yapıldığı her iki yılda da serin mevsim yem bitkisi olan yonca bitkisinin ham protein oranlarının buğdaygil yem bitkilerine göre yüksek olduğu görülmektedir (Tablo 5). Bunun nedeni olarak; sıcak mevsim buğdaygil yem bitkilerinin C4 bitkisi olması nedeniyle, hızlı bir kuru madde birikimine ve bunun sonucunda bitki dokularındaki azotun daha seyreltik hale gelmesi ile bitkideki ham 
protein oranının düşmesi ile açıklamak mümkündür (Jones, 1985). Ayrıca araştırmada 2017 yılının ham protein verimleri 2016 yılındakilere göre daha yüksek bulunmuştur. Bu nedeni olarak yıllar arasındaki kuru madde verimlerinin farklı olması gösterilebilir (Tablo 5, 6) (Avcı, 2000).

Sindirilebilirlik otlardaki selüloz, hemiselüloz ve lignin gibi hücre duvarını oluşturan madde miktarlarıyla ilişkilidir. Son yıllarda otlardaki sindirilebilirlik oranları asit deterjanda çözünmeyen lif (ADF), nötral deterjanda çözünmeyen lif (NDF) üzerinden hesaplanmaktadır. ADF, daha çok bir kaba yemin hayvan tarafından sindirilebilirlik durumunun belirlemesinde kullanılan bir yem değeri iken, NDF ise kaba yemlerin hayvanlar tarafından alınabilirlik durumlarının saptanmasında kullanılan bir yem değeridir. İyi bir ot kalitesi için $A D F$ ve NDF değerlerinin mümkün olduğu kadar düşük olması istenilmektedir (Aheaffer ve ark., 1995; Başbağ ve ark., 2018, Lacefield, 1988; Linn ve Martin,1999; Sayar ve ark., 2014; Schroeder, 1994;). Tablo 6 ve Tablo 7'de araştırmada uygulamalardan saptanan ADF ve NDF oranları incelendiğinde; saf yonca uygulamasının, bu iki özellik bakımından diğer uygulamalardan daha düşük değerlere sahip olduğu görülmektedir. Bunun nedeni olarak; bir baklagil yem bitkisi olan yoncanın, ADF ve NDF içeriklerinin buğdaygil yem bitkisi türlerine göre daha düşük olmasından kaynaklandığı söylenebilir (Linn ve Martin, 1999).

Sindirilebilirlik kaba yemlerde önemli bir kalite kriteridir. Kaliteli bir kaba yem için sindirilebilirliğinin mümkün oldukça yüksek olması arzu edilir. Çünkü kaba yemlerde yüksek sindirilebilir kuru madde oranı (SKMO), hayvanların yemi rahat tüketmesini sağladığı gibi, aynı zamanda et ve süt gibi hayvansal ürünlere dönüşme oranını da arttırır. Sindirilebilir kuru madde oranları ADF oranları ile negatif ilişki içerinde olduğundan (Sheaffer ve ark., 1995) saf yoncada, düşük olan ADF oranına bağlı olarak yüksek çıkan sindirilebilir kuru madde oranı saf buğdaygil ve buğdaygil karışımlarında daha düşük olarak bulunması (Tablo 6,7$)$ beklenen bir sonuçtur. Nitekim, Linn ve Martin (1999), baklagil yem bitkilerinin buğdaygil yem bitkilerine göre daha yüksek ham protein oraranına bunun yanısıra daha düşük $A D F$ ve NDF içeriğine sahip olduğunu, $A D F$ orandaki selüloz ve ligninden dolayı sindirilebilir kuru madde oranları ile yakından ilgili olduğu ve bu oranın da sindirilebilir-liği etkilediğini ifade etmek mümkündür.

Linn ve Mart'in (1999), baklagil yem bitkilerinin buğdaygil yem bitkilerine göre daha az ADF ve NDF, bunun yanı sıra daha fazla protein ve sindirilebilir kuru madde oranları içerdiğini belirtmişlerdir. Karışım parsellerinde yonca kapasitesinin artması ile ADF oranlarında doğal olarak düşüş gerçekleşmiş olup bu da sindirilebilir kuru madde oranının artmasına ve dolayısıyla yem kalitesinin artışına neden olmaktadır.

Sonuç olarak; Şanlıurfa koşullarında en yüksek kuru madde verimi ile en yüksek ot kalite değerleri saf yonca uygulamasında saptanmıştır. Bu yüzden kuru ot elde etme amaçlı yem bitkisi yetiştiriciliklerinde saf yoncanın yetiştirilmesi uygun olacaktır. Ancak otlatma amaçlı suni mera tesislerinde ise şişme problemi nedeniyle saf yonca uygulaması yerine, rodos otu, adi yalancı darı ve köpek dişi ayrığı türlerinin yonca ile birlikte oluşturacakları karışımlarla çok yıllık mera tesisi, bu buğdaygil türlerin saf uygulamalarına göre sindirilebilir kuru madde oranı ile ot kalite özelliklerinde önemli bir artış yapacağı sonucuna varılmıştır.

\section{Kaynaklar}

Açıkgöz E, 2001: Yem bitkileri, yenilenmiş 3. baskı. Uludağ Üniversitesi ZiraatFakültesi Tarla Bitkileri Bölümü. Uludağ Üniversitesi Vakfı yayın no, 182. $584 \mathrm{~s}$, Bursa.

Açıkgöz E, Hatipoğlu R, S Altınok, C Sancak, A Tan, D. Uraz, 2005: Türkiye Ziraat Mühendisliği VI. Teknik Kongresi, 3-7 Ocak 2005, Ankara.

Albayrak S, 2003: Ankara ekolojik koşullarında yapay mera kurulması üzerine bir araştırma. Doktora tezi, Ankara Üniversitesi Fen Bilimleri Enstütüsü Ankara.

Altın M, Gökkuş A, Koç A, 2005: Çayır mera ıslahı, Tarımsal Üretim ve Geliştirme Genel Müdürlüğü, Ankara.

Avcı M, 2000: Çukurova' da yapay mera kurmak amacıyla yetiştirilebilecek kışlık çok yıllık buğdaygil + baklagil yem bitkileri karışımlarının saptanması. Çukurova Üniversitesi Fen Bilimleri Enstitüsü, Tarla Bitkileri Anabilim Dalı, Doktora Tezi, Adana.

Avcıoğlu R, Akbari N, Soya H, Sabancı I, 1991: Ege sahil kuşağında yapay çayır- mera kurma olanakları üzerinde araştırmalar. Türkiye 2. Çayır Mera ve Yem Bitkileri Kongresi, 28-31, Mayıs 1991, s, 181-190, İzmir.

Avcıoğlu RN, Soya H, 2009: Köpekdişi ayrığı (Cynodon dactylon L. Pers) darılar, buğdaygil ve diğer familyalardan yem bitkileri, (Avcıoğlu R, Hatipoğlu R, Karadağ Y, editör) Cilt III. TÜGEM, Emre Basımevi, s:727-732, İzmir.

Bakır Ö, 1985: Çayır ve mera ıslahı prensip ve uygulamaları. Ankara Üniversitesi Ziraat Fakültesi Yayınları, no,947, Ders kitabı, 272, s: 25-30, Ankara.

Ball DM, Collins $M$, Lacefield GD, Martin NP, Mertens DA, Olson KE, Putnam DH, 
Undersander DJ, Wolf MW, 2001: Understanding forage quality. American Farm Bureau Federation Publician 1-01, Park Bridge, IL.

Başbağ M, Çaçan E, Sayar MS, 2018: Bazı buğdaygil bitki türlerinin yem kalite değerlerinin belirlenmesi ve biplot analiz yöntemi ile özelliklerarası ilişkilerin değerlendirilmesi. Tarla Bitkileri Merkez Araştırma Enstitüsü Dergisi, 27 (2): 92-101.

Chessmore RA, 1975: Profitable Pasture Management. THA Instertate Printers and Publishere, inc $421 \mathrm{p}$.

Çınar S, 2012: Çukurova taban koşullarında bazı çokyıllık sıcak mevsim buğdaygil yem bitkilerinin yonca (Medicago sativa L.) ile uygun karışımlarının belirlenmesi. Doktora Tezi, Çukurova Üniversitesi Fen bilimileri Enstitüsü, Tarla Bitkileri Anabilim Dalı, Adana.

Geçit H, Çiftçi CY, Emeklier Y, Ikincikarakaya S, Adak MS, Kolsarıcı Ö, Ekiz H, Altınok S, Sancak C, Sevimay CS, Kendir H, 2009: Tarla bitkileri bölümü, Ankara Üniversitesi Ziraat Fakültesi Yayınları, Yayın no, 1569, Ders kitabı, 521, Ankara.

Hatipoğlu R, Tükel T, 2009: Leuceana (Leuceana leucocephala (Lam.) de Wit), Yembitkileri, baklagil yembitkileri, Cilt II, R Avcıoğlu, R Hatipoğlu, Y Karadağ, Ed., Tarım ve Köyişleri Bakanlığı Yayınları, 520-524, İzmir.

Jones CA, 1985: C4 Grassess and cereals. John Willey\&Sons, Newyork.

Lacefield GD, 1988: Alfalfa hay quality makes the difference. University of Kentucky, department of agronomy AGR-137, Lexington, KY.

Linn JG, MartinNP, 1999: Forage quality tests and interpretations, Erişim: http://extension.umn.edu/distribution/livesto cksystems/ID2637.html.

Karadağ Y, U Büyükburç, 2004: Forage qualities, forage yields and seed yields of some legumetriticale mixtures underrainfed conditions. Acta Agriculturae Scandinavica, Section B- Soil \& Plant Sci, 54, 140-148.

Kendal E, Sayar MS, Tekdal S, Aktaş H, Karaman M, 2016: Assessment of the impact of ecological factors on yield and quality parameters in triticale using GGE biplot and AMMI analysis. Pakistan Journal of Botany, 48(5): 1903-1913.

Sayar MS, Anlarsal AE, Başbağ M, 2010: Güneydoğu Anadolu Bölgesinde yem bitkileri tarımının mevcut durumu sorunları ve Çözüm önerileri. Harran Üniversitesi Ziraat Fakültesi Dergisi, 14(2): 59-67, Şanlıurfa.

Sayar MS, Anlarsal AE, Başbağ M, 2013: Genotypeenvironment interactions and stability analysis for dry-matter yield and seed yield in
Hungarian vetch (Vicia pannonica CRANTZ.). Turkish Journal of Field Crops, 18(2): 238-246.

Sayar, M.S, Kendal E, 2014: Tek yıllık baklagil yem bitkilerinin tahıllarla karışık ekimi. Mardin Gıda Tarım ve Hayvancılık Dergisi, 4, (11): 52-54.

Sayar MS, Han Y, Yolcu H, Yücel H, 2014: Yield and quality traits of some perennial forages as both sole crops and intercropping mixtures under irrigated conditions. Turkish Journal of Field Crops, 19(1): 59-65.

Sayar MS, Han Y, Başbağ M, Gül I, Polat T,2015: Rangeland improvement and management studies in Southeastern Anatolia Region of Turkey. Pakistan Journal of Agricultural Sciences, 52(1): 9-18.

Sayar MS, 2017: Ülkemiz ve bölgemizdeki yem bitkisi tarımına genel bir bakış. Diyarbakır'da Tarım Dergisi, 28, 30-34.

Schroeder JW, 1994: Interpreting forage analysis. Extension Dairy Specialist (NDSU), AS-1080, North Dakota State University.

Serin Y, Gökkuş A, Tan M, Çomaklı B, Koç A, 1997: Otlakiye amacıyla kullanılabilecek baklagil ve buğdaygil yem bitkileri bunların karışımlarının belirlenmesi. Tarla Bitkileri Merkez Araştırma Enstitüsü Dergisi, 6(1): 15-26.

Serin $Y$, Tan $M$, 2009: Buğdaygil yem bitkilerinin tarımsal özellikleri, ekonomik önemleri, Taksonomileri ve Genel Yapısal Özellikleri, Buğdaygil ve Diğer Familyadan Yem Bitkileri, (Avcıoğlu R, Hatipoğlu R, Karadağ Y, ) cilt III. TÜGEM, Emre Basımevi, s. 546-549, İzmir.

Sheaffer CC, Peterson AA, Mccalin M, Volene JJ, Cherney JH, Johnson KD, Woodward WT, Viands DR, 1995: Acid detergent fiber, neutral detergent fiber concentration and relative deed value, North American Alfalfa Improvement Conference, Minneapolis.

Vallentine JF, 1980: Range development and improvement, brigham young young. University Press, Provo, Utah, s. 357-358.

*Yazışma Adresi: Habip ARTAN

Harran Üniversitesi Mühendislik Fakültesi, Bilgisayar Mühendisliği Bölümü, Osmanbey Kampüsü/Şanlıurfa.

e-mail: hartan@harran.edu.tr 